\title{
Cocaine trafficking from non-traditional ports: examining the cases of Argentina, Chile and Uruguay
}

\section{Carolina Sampó ${ }^{1,2} \mathbb{D} \cdot$ Valeska Troncoso ${ }^{3}$}

Accepted: 26 November 2021

(c) The Author(s), under exclusive licence to Springer Science+Business Media, LLC, part of Springer Nature 2021

\begin{abstract}
This article presents the results of an exploratory study aimed to analyze the contexts in which the use of Non-Traditional ports of cocaine departure and counterintuitive routes is prioritized, based on the experience of Argentina, Chile, and Uruguay. Moreover, we show that criminal organizations prioritize the Ports of Buenos Aires, San Antonio and Montevideo, and the counter-intuitive routes that lead to them, because they are spaces that generate incentives linked to the porosity of borders, the lack of control at the ports, and the possibility of exploiting the country's lack of reputation for drug exportation to re-export cocaine undetected. This study constitutes a precedent for future research on the role of South American Southern Cone ports in cocaine trafficking. We can identify at least four emerging lines of research: 1 . Cocaine trafficking from landlocked countries; 2 . The role of the waterway Paraná-Paraguay; 3. The link between Non-Traditional ports of cocaine departure and new markets; and 4. Other Non-Traditional Ports of cocaine departure, which are not containerized.
\end{abstract}

Keywords Drug trafficking $\cdot$ Ports $\cdot$ Routes $\cdot$ Cocaine $\cdot$ Argentina $\cdot$ Chile $\cdot$ Uruguay

This work was produced within the framework of the project UBACyT 20020190200243BA named «El surgimiento de nuevas estructuras criminales en Sudamérica: La dinámica del crimen organizado en Argentina y Brasil (2015 - 2019)».

Carolina Sampó

carosampo@gmail.com

Valeska Troncoso

valetroncosoz@gmail.com

1 Consejo Nacional de Investigaciones Científicas y Técnicas (CONICET), International Relations Institute (IRI) University of La Plata (UNLP), Argentina, Calle 48 582, 5th floor, B1900, La Plata, Provincia de Buenos Aires, Argentina

2 University of Buenos Aires (UBA), Buenos Aires, Argentina

3 Center for Studies on Transnational Organized Crime, International Relations Institute (IRI), University of La Plata (UNLP), La Plata, Argentina 


\section{Introduction}

Researchers have long been studying and writing about the routes and methods used by organized crime to smuggle drugs from South America (Bartolomé 2016; Bartolomé 2019; Bartolomé and Ventura 2020; McDermott et al. 2021; Sampó 2019a: Sampó 2019b) and from the Southern Cone (Bartolomé 2016; Bartolomé and Ventura 2020; Ewig 2017; Sampó 2017a; Sampó 2017b; Souto Zabaleta et al. 2019; Troncoso 2017). Nevertheless, an especially important part of this scheme appears to have been neglected: ports and their role in drug trafficking. Even though some scholars have started working on this topic, specifically cocaine ports of entry (Antonelli 2020a; Antonelli 2020b; Roks et al. 2020; Lantsman 2017; Sergi 2020a; Sergi and Storti 2020;) the ports of cocaine departure located in South America have been scarcely studied (Jenss 2020; Zaitch 2001; Zaitch 2002), despite their relevance within the supply chain of illicit goods.

Since South America is the region of the world where the vast majority of coca bush is cultivated and cocaine is produced, and Colombia, Peru and Bolivia, in that order, almost have the monopoly of that production, ${ }^{1}$ it is important to understand how criminal organizations manage to supply the cocaine demand from abroad. Especially now since, as Anguita Olmedo (2020: 179) claims, "Both the range of drugs and the drug markets are expanding and diversifying as never before."

Since 2014, coca bush cultivation and cocaine production have grown enough to flood South America (Sampó and Ferreira 2020) forcing drug trafficking organizations to depend much more on maritime routes to smuggle as much cocaine as possible, producing a spillover effect beyond the producing countries. According to the UNODC (2020) World Drug Report, ${ }^{2}$ in 2014,869 tons of cocaine at $100 \%$ purity were produced from coca bush cultivation in Colombia, Peru, and Bolivia while, in 2018, 1723 tons were produced, representing a more than doubling of growth in only four years. In this regard, the production is still growing while crop eradication has been reduced in the last two years. At the same time, supply as well as the demand from the Global North have grown not only in Europe but also in new markets such as China, Australia, and New Zealand as well as in South America. Moreover, Europe has become a more tempting market not only because of the price of cocaine in that territory but also because it opens the door to the Middle East and Asia (Mcdermott et al. 2021).

In this context, studying cocaine trafficking from South American ports and maritime routes is becoming increasingly necessary. In this article, we work from the understanding that criminal organizations use certain Non-Traditional ports of cocaine departure and counter-intuitive routes (as we will define below) to reduce

\footnotetext{
${ }^{1}$ Some small plantations have been discovered in Central America (Panamá, Guatemala, Honduras) and Mexico. Nevertheless, considering that, according to UNODC (2020), the cultivation of coca bush in Colombia, Peru, and Bolivia is larger than 240,000 ha, it does not seem relevant to add what appears to be very small productions (seizures in different countries were from around $20 \mathrm{ha}$ ).

${ }^{2}$ UNODC has published data presented by countries until 2018 only, even when the latest publication was 2020 .
} 
risks and maximize profitability (Zaitch 2002). We refer to this strategy of using ports and routes not typically associated with the drug trade to launder and disguise the origin of the drugs as "re-exportation." This article aims to analyze the contexts in which the use of Non-Traditional ports of cocaine departure and counter-intuitive routes is prioritized, based on the experience of Argentina, Chile, and Uruguay. The latter present diverse manifestations of organized crime but have been inadequately studied (Zaitch 2019). In recent years, these transit countries have gained importance in maritime cocaine trafficking and, because they are not considered critical source countries by the law enforcement institutions and Customs departments of entry ports, criminal organizations take advantage of the weaker control that exists in their ports.

We believe that understanding how criminal organizations use Non-Traditional ports and counter-intuitive routes allows us to explore little-known aspects of cocaine trafficking from South America. The ports of Buenos Aires (Argentina), San Antonio (Chile), and Montevideo (Uruguay) are of particular interest as they are considered countries with low organized crime penetration and low levels of public violence, so they seem to be off the authorities' radar. As a result, criminal organizations re-export cocaine from the Southern Cone countries, taking advantage of their reputations regarding drug trafficking, as we will explain below. As Mcdermott et al. (2021: 7) points out: "Well aware that European authorities are paying special attention to containers arriving directly from cocaine-producing countries - Colombia and Peru - traffickers are using other dispatch points in the region."

The main research question explored in this article is: What facilitating factors and incentives lead criminal organizations to use counter-intuitive routes and NonTraditional ports such as Buenos Aires, San Antonio, and Montevideo?

Our analysis contributes to the discussion of the drug trafficking phenomenon by incorporating the perspective of the Global South. This article is divided into four parts. First, we outline the research notes. Second, we establish the importance of ports for criminal organizations, and define what we understand as counter-intuitive routes and Non-Traditional ports. Third, we identify the context of Buenos Aires, San Antonio, and Montevideo, analyzing geographical, infrastructure, and sociopolitical factors. Fourth, we analyze facilitating factors and incentives generated by the ports of Buenos Aires, San Antonio, and Montevideo. Finally, we draw some conclusions.

\section{Research notes}

This article presents some of the findings of a broader and ongoing qualitative research project focused on the evolution of criminal organizations in South America. A review of the specialized literature showed the scarcity of information on organized crime in the ports of the Southern Cone, and therefore, the need for smaller-scale research that is useful for investigating under-studied issues (Swedberg 2020). Hence, the nature of this study is exploratory.

We focus our analysis on the most important container ports of the Latin American Southern Cone-Buenos Aires, San Antonio, and Montevideo-considering: 1. 
That they have a more important role in cocaine trafficking to Europe and to the socalled new markets (particularly to Asia and Oceania); 2. Container contamination is the most common method used to transport cocaine particularly to Europe and new markets (CIMCON 2020); and, 3. Their geographic proximity with two of the main cocaine producers, Peru and Bolivia, and the most important transit country, Brazil.

Even though each country presents particularities regarding the management of ports, port security as well as how they manage the national maritime space (understood as the space between the coast and 200 maritime miles), it is important to highlight that the countries we focus on are spaces of transit that share borders with countries that actually cultivate coca bush and produce cocaine, except for Uruguay, which gained importance due to its proximity to Brazil and the existence of the waterway (Hidrovia Paraná-Paraguay), as we will argue. None of them is considered a traditional hub for drugs even though Chile is the third country from which Europe receives the most cocaine through containers (Fiscalía de Chile 2020).

In this research, two techniques were used to gather information: a bibliographic review and in-depth interviews.

The literature review was carried out with a double purpose, methodological and thematic. This implied a permanent review of the literature. Through searches in different databases, we identified and selected books and scientific articles, official reports from international organizations, and official documents produced by the countries studied. The information gathered was systematized in a thematic bibliographic file and consolidated in bibliographic cards. These files were systematically reviewed and supplemented during the research process.

In-depth interviews were conducted with 10 key informants. Among them were academics, officials of Customs, members of Federal Forces, and officials (or former officials) of Security institutions, selected based on the knowledge and experience they could provide on regional trends and selected ports. Key informants were selected by purposive sampling and the strategy implemented was snowballing. From the first two interviews, a network of contacts was generated that made it possible to contact informants who were difficult to reach.

The data collected was transcribed after each interview and coded thematically. In the first instance, deductive coding was carried out based on the research question. Then inductive or open coding was carried out to establish more specific themes and others that emerged from the interviews.

In relation to ethical issues in the interview process, an effort was made from the first contact with the interviewees to inform them of the nature of the research. To guarantee the confidentiality of the interviews and protect the identity of the informants, a reference was assigned.

The present research has some limits that need to be considered. Because of the Covid-19 pandemic, on-site field work in the selected ports was impossible to carry out. A second limitation was that government authorities have invoked security reasons in order not to share updated relevant information regarding the modus operandi of criminal organizations despite our official requests. Finally, a third limitation was pointed out by key informants who agreed that there is a lack of well collected official data in the three countries. These latter limitations have already been 
addressed in other publications, both for the study of organized crime in general (Hobbs and Antonopoulos 2014; Vander Beken and Drefruytier 2004; von Lampe 2004) and for the study of ports in particular (Sergi 2020a).

As we will argue in the conclusions, this work opens several research lines that will require further work in the future.

\section{Ports, routes, and criminal organizations}

Ports and routes are two central elements of maritime transport that allow the movement of $80 \%$ of international trade (Guterres 2020), favoring the sustained development of the supply chain from different latitudes. The global scope is reflected in the latest UNCTAD report ( 2020). It is estimated that the total volume of maritime trade in 2019 was 11.08 billion tons and per container ports worldwide handled 811.2 million TEUs. ${ }^{3}$

Ports are fundamental for the economic and commercial growth of countries, as they enable international trade exchange. Due to its border as well as commercial nature (Sergi 2020a, 2020b, 2020c), they are the main spaces for the exchange of goods (Antonelli 2020a), and inevitably act as an interface between illegality and legality (Roks et al. 2020). As a foreign trade specialist explains: "drug trafficking rides on the back of logistics and uses commercial logistics to commit the crime,"

\section{Ports and criminal organizations}

The ports are complex spaces. They are a gateway both for the entry and departure of illicit drugs (Sergi 2020a:2), and criminal organizations operate and expand their business using advantages produced by port vulnerabilities (Lantsman 2017; Madsen 2018; Moiseienko et al. 2020; Sergi et al. 2020; Sergi and Storti 2020; Antonelli 2020a; Roks et al. 2020; Sergi 2020b). The vulnerabilities of the port itself are not the only important factor; the spatial context in which they are inserted is also key (Madsen 2018). In the case of the ports of Buenos Aires, San Antonio, and Montevideo the geographical space that connects them with the production centers is also relevant.

Criminal activities in the ports can be promoted by an enabling environment (Antonelli 2020b) that provides a privileged context for criminal organizations to obtain economic benefits and exercise power (Madsen 2018). That makes ports more prone to a certain degree of criminal governance (Arias 2006; Arias 2017; Lessing 2020; Sergi and Storti 2020) where the state and non-state actors interacting in these spaces generate a network of social behaviors (Antonelli 2020a; Madsen 2018; Sergi and Storti 2020) through formal and informal links that favor the establishment of organized crime.

\footnotetext{
3 TEU is a standard measuring unit, equivalent to a $20-\mathrm{ft}$ container.
} 
Criminal organizations should be considered rational actors, as Zaitch (2002, p. 240) argues: "as rational actors, their perceptions about particular resources or business environments - in this case the port of Rotterdam - can be regarded to a certain extent as risk assessments". Hence, Zaitch continues, "cocaine entrepreneurs and employees do calculate chances of success and failure and deploy strategies to minimise risk" (Zaitch 2002, p.240).

Failures in ports control are incentives for cocaine trafficking from South America to consumer markets abroad. Both Police and Customs surveillance and control have failed to be effective, particularly when drugs can be hidden within or alongside legitimate maritime traffic, such as fishing vessels or cargo ships (Bueger and Edmunds 2020). Nevertheless, control does not always guarantee the triumph of state forces. As Sergi (2020c: p.5) and Zaitch (2002) point out: the increase of security measures displaces certain activities but also creates new opportunities for illicit traffic.

Nevertheless, the choice of ports and routes is not random but rather responds to the opportunities that criminal organizations see in them since they are rational actors. According to a Brazilian officer, alternative routes are used to amplify criminal organizations' profits because, in their business model, sending cocaine through traditional routes implies a loss of around 20\%. "By using alternative routes, they amplify the profit of the whole business, because in the alternatives the chances of seizure are much lower" claimed the Brazilian Officer. A Colombian officer confirms those estimations, explaining, "the risk factor that they manage of loss, that they take into account that this $2 \%$ allows them to have a success, a favorability of $80 \%$ or so" (the $2 \%$ mentioned refers to the percentage of containers that are checked by authorities).

\section{Defining counter-intuitive routes and non-traditional ports of cocaine departure}

In this article, we argue that the routes used by criminal organizations serve a rational choice where greater criminal mobility (Morselli and Royer 2008) reflects greater selectivity and a high level of thinking and planning, as well as allowing for greater economic returns.

These are counter-intuitive routes from the government perspective, which escape traditional logic and do not respond exclusively to the lowest cost-most profit dynamic. Rather, they benefit from the inconveniences of routes that are not very accessible, whether due to natural, political, or economic factors, which, although they may imply a higher economic cost, provide greater security, avoiding police and customs controls. In other words, these are routes that involve fewer risks, thus improving their positioning compared to more traditional ones. They are not the closest geographically, the shortest in terms of time, nor necessarily the cheapest routes. Such counter-intuitive routes refer to land, air, river, or even sea routes that do not make apparent geographical or economic sense and therefore, allow criminal organizations to re-export drugs while maintaining low risk, as we will see below.

Non-Traditional ports of cocaine departure are understood as those ports that are not located in coca bush producing countries, as well as those that have been 
identified as clear transit areas. On the contrary, they are located in countries where the government does not recognize transnational drug trafficking as a real problem. Also, these ports are not being highlighted by the international community as cocaine departure ports so when a ship leaves the departure port, there are no alarms ringing in the ports of arrival, according to a Colombian officer we interviewed. McDermott et al. (2021: 46) support this notion, claiming that "evidence indicates that traffickers are turning to ports with a relatively clean commercial record that are not well-equipped to contain the flow of cocaine, as is the case in Argentina, Uruguay and Chile."

As Sergi points out (2020c, p.10), routes and ports work together but may change: "Indeed, a safer (that is, less patrolled) journey by sea - with a less controlled route - might justify using another port, even one that is far away" and so "A trafficker or an importer might prefer to use a port in another region/province or even another state and then transport the drugs by car for five days or a week if the door in the other port is safer than any other door" (Sergi 2020c p.10). In sum, risk is the most important variable considered by criminal organizations.

According to the UNODC (2020:32) World Drug Report, "Traffickers appear to be diversifying the routes and departure points used to traffic cocaine from South America to Europe and West Africa." For instance, Venezuela used to be a major departing port but due to political and security instability, criminal organizations seem to have reduced its use widely (UNODC 2020:32). On the contrary, Brazil has gained importance and Uruguay appears to be a new departure space, even though the route seems counter-intuitive at a glance. In short, we need to bear in mind, on the one hand, that criminal organizations use more than one route and departing port and, on the other, that counter-intuitive routes may be an ace up their sleeves especially in times of crisis. Criminal organizations have a portfolio from where to choose, so they use the most convenient route and port for a particular moment, always considering the cost-benefit equation in terms of risk.

In the following section, we will analyze the context in which Buenos Aires, San Antonio, and Montevideo are located and explain why they have become very good options for criminal organizations smuggling cocaine overseas.

\section{The world around the cocaine departure ports: the Argentina, Chile, and Uruguay context}

In recent years, cocaine trafficking in South America has been changing. Colombia has played an important role in this change; according to a Peruvian academic, this is mainly due to the impact that anti-drug policies have had on South American countries. On this situation, the informant points out: "it is impressive how the Colombians have broken records in the eradication of illicit crops and cocaine seizures, but what this has caused is a displacement towards the south, let's say of all drug trafficking." Meanwhile, a Colombian officer explains, "That is the balloon effect. By generating contain in Colombia's ports, criminal organizations seek to expand their criminal framework, they are looking for the easiest way out." This represents, on 
Table 1 Port throughput in TEUs by port and port area (South America)

\begin{tabular}{lll}
\hline Position & Name of port and port area & $\begin{array}{l}\text { Throughput } \\
\text { (TEU) 2018 }\end{array}$ \\
\hline 1 & Santos port area, Brazil & $3,836,487$ \\
2 & Bay of Cartagena, Colombia & $2,862,787$ \\
3 & El Callao, Peru & $2,340,657$ \\
4 & Guayaquil, Ecuador (Port Area and & $2,064,281$ \\
& private terminals) & \\
5 & Buenos Aires, Argentina & $1,797,955$ \\
7 & San Antonio, Chile & $1,660,832$ \\
8 & Buenaventura, Colombia & $1,369,139$ \\
9 & Itajaí port area, Brazil & $1,045,813$ \\
10 & Valparaiso, Chile & 903,296 \\
\hline
\end{tabular}

Source: Taken and adapted from CEPAL (2019)

the one hand, a repositioning of coca bush and cocaine production towards Peru and Bolivia, and on the other hand, the redefinition of routes further south.

As a result, the countries of the Southern Cone appear to be playing a more important role in drug trafficking. According to a Peruvian academic, "the traditional Pacific and Caribbean routes are quite complicated and that also means that the dynamics are moving towards Uruguay, Argentina and Chile." Due to their proximity to Peru and Bolivia, these countries are important because they allow cocaine to be exported to international markets through their ports (CIMCOM 2018).

To understand why the organizations use the ports of Buenos Aires, San Antonio, and Montevideo to re-export cocaine, it is necessary to consider: first, the spatial context and the infrastructure the port has; and second, the socio-political context of the countries in which these ports are located.

\section{Geographic and infrastructure factor}

The geographic space in which these countries are located provides criminal organizations with the conditions for extensive internal and cross-border mobility. This favors the use of routes that may appear to be longer and more expensive but ensure a low-risk, high-return scenario. These are counter-intuitive routes that defy the security forces' pre-existing logic of how criminal organizations traditionally transport cocaine.

The three ports we studied are located in different countries and, although they share some characteristics, have some significant differences. Firstly, San Antonio is located in the Pacific Ocean while Buenos Aires and Montevideo face the Atlantic. San Antonio is situated in the region of Valparaíso, close to Santiago de Chile, which is landlocked (surrounded by mountains). On the contrary, Buenos Aires and Montevideo's ports are in the middle of capital cities.

All three ports are the most important door to the sea for their countries and move a considerably large volume of trade, as shown in Table 1. 
Buenos Aires concentrates $90 \%$ of the containers in Argentina and it is the most important port of the country. According to CEPAL (2019), it is the fifth-ranked port of South America regarding container cargo movements. It moves more than 1,400,000 TEU a year. San Antonio is 6th, moving more than 1,200,000 TEU a year and Montevideo is 10th with 900,000 a year. CEPAL (2020) identifies them as the most important ports according to commercial activities in Argentina, Chile, and Uruguay. Further, the routes and frequencies of the shipments departing Buenos Aires, San Antonio, and Montevideo, according to key informants, show a regular connection between these ports and the container ports identified as cocaine ports of entry (Antwerp, Rotterdam, Algeciras, Valencia, Barcelona, Le Havre, and Hamburg, according to a Colombian officer).

As a Colombian officer describes:

It makes it easier for them to use the containers because the freight is practically free. They do not even have to invest in the vessel, because the means of transport is a normal commercial line, the container issue, well they have to pay those who do the contamination, but it is minimal what they pay and coordinate with port coordinators so that they go out and that's it.

In addition, these departing ports have a consolidated transport infrastructure network. The Global Competitiveness Report 2019 (World Economic Forum 2019) that evaluates connectivity to the global maritime network and efficiency to port services places Chile, Uruguay, and Argentina (in that order) as the most competitive economies in the region with high scores in port infrastructure. Therefore, they are ports of high attraction for criminal organizations. As Zaitch (2002: p.245) claims:

local cocaine traffickers considered that good communication infrastructure (train connections, good highways, public and mobile telephone facilities, and so on) are central for business performance, especially since the cocaine trade consists of connecting people who live and work far from each other.

\section{Socio-political factors}

Transborder relations in South America are very common and sometimes, like in the case of Arica (Chile) and Tacna (Peru), is easier for the people to go from one city to the other even when this involves "crossing a border" than to go to a bigger city in their own country. As one academic interviewed highlights: "Between Peru and Chile they move, well before Covid, I don't know how many millions of people a day, the people who live in Arica go to lunch, to buy their toilet paper there, they go to the dentist there, the Peruvians pass to Arica to do different things." The same dynamic is seen on the Argentina-Bolivia and Uruguay-Brazil borders, making cross-border movement very difficult for authorities to control.

For Idler (2019), this is conducive to a low-risk, high-opportunity environment and these border areas constitute strategic corridors for criminal organizations and drug trafficking. A Uruguayan officer confirms this dynamic also when it comes to criminal organizations: 
In the border cities with Brazil, there is a lot of trouble. They are groups of Brazilian criminals, "bala na cara", "tiro na cara", who dominate the sale of narcotics in these binational cities. They are small, they are people who enter and leave through dry borders that nobody controls. Little is known, but they have the power to control the territory and do whatever they want.

The statement is confirmed by a Chilean academic: "the passages between Peru and Chile, and Bolivia and Chile are open passages, you can walk from one side to the other." The same is seen between Argentina and Bolivia, and Argentina and Paraguay. According to official information, there are more than 200 irregular passages over each border.

It is important to highlight that corruption is quite normalized in Argentina and seems to penetrate society and government equally. According to Transparency International (2021), Argentina is ranked 78th (from 180 places), while Uruguay and Chile, where corruption exists but is still not generalized, are placed 25th and 21st, respectively. Hence, for these three countries of the region, perception of corruption has always been close to world average. According to an academic and former officer, Chile and Uruguay are starting to see the penetration of corruption at the lowest political levels, while in Argentina it has long existed.

Regarding Chile, particularly, an academic highlights:

There must be a significant level of corruption in the institutions that are allowing drugs to enter from Peru, either through the border with Peru, the border with Bolivia or, in some cases, the border with Argentina, which are like the three areas where the borders are very porous and there is no capacity for concentration

This statement reminds us that limits between corruption and State control capacities are very diffused. The same academic also points out that "recognizing the presence of organized crime is recognizing the presence of corruption," but since Chile has a tradition regarding low corruption levels, "here you say there has to be corruption and the whole institutional framework is thrown at you because it is indeed a very serious issue." In fact, the social and political condemnation due to corruption crimes may be considerably strong in Chile and in Uruguay.

In the case of Argentina, as mentioned, corruption is normalized, as we can infer from the words of a foreign trade specialist when talking about Customs, implying that if corruption exists when it comes to a licit business, it should be much more important when analyzing illicit economies. In his words, "Customs is the one that decides whether to open a container or not"; Security Forces cannot do it on their own, they must have a court order to do so. As an Argentinian officer claims, there exists an: "undoubted connivance between customs officers, police officers."

On the other hand, levels of violence in the three countries have remained low compared to what happens in the rest of the region. Considering the last global homicides report (UNODC 2019), Chile only has 3.5 homicides per 100 thousand inhabitants while Argentina reaches 5.1 and Uruguay has more than 11. According to the same report, violence related to organized crime in Argentina, Chile, and Uruguay is not as widespread as in Mexico. Nevertheless, threats and aggressions 
have increased and even while homicides remain considerably low, they are concentrated in "hot spots," especially in suburban areas where micro trafficking continues to grow. However, no higher levels of violence have been identified in the port areas.

\section{Counter-intuitive routes and non-traditional ports of cocaine departure from the Southern Cone: Buenos Aires, San Antonio, and Montevideo}

Understanding how the ports of Buenos Aires, San Antonio, and Montevideo have become spaces that generate incentives for criminal organizations is a research exercise that implies a holistic approach, which allows us to explore the different dimensions of the phenomenon.

The ports of Buenos Aires, San Antonio, and Montevideo have been characterized throughout history as key places for the exchange of goods and links between cultures and people. These ports are spaces that have a place in the heterogeneous, multicultural, and multiethnic history of South America. This leads to the issue of the indissoluble relationship between physical space and space-society; that is, understanding space as socially constructed (Massey 2012; Lefebvre 2013).

This idea has a key role in studying cocaine trafficking from these three ports. Sergi points out that "ports are unique environments; they are universes of processes and meanings" (Sergi 2020b, p.17). Hence, the focus cannot be reduced to port facilities alone since they are very different from what Augé (1993) calls "nonplaces", such as airports and hotels. Space is not a given condition, it is a factor of transformation, a cultural and ideological instance integrated by diverse actors (Santos 1996). In this sense, the organized crime spaces we study exceed the port/city. This geographic space ranges from production areas to the land, river, air, and even sea routes leading to the ports (Labrousse 2012).

Therefore, if in the economic-commercial logic, time values the space/port, criminal organizations value these Non-Traditional Ports, as they provide them with safety and greater economic returns, even though they make the process take longer. As a result, these are opportunities and facilitating factors (Von Lampe 2015) and not because of the existence of a deep link between criminal organizations and the constructed space, as would be the case for mafia-type organizations.

In the Southern Cone, criminal organizations, unlike their Colombian and Mexican counterparts, are not exclusively dedicated to drug trafficking. On the contrary, the logistics built around illegal products allow them to develop different activities and transport different goods, as demonstrated by smuggling.

Criminal organizations in Argentina (Sampó and Quirós 2018), Chile, and Uruguay seem to be small organizations, linked by familiar bounds. Nevertheless, according to an Argentinian officer, recently "a scheme of multiple and variable associations" has risen. That is, the market is very atomized; it "is like a universe of actors that are intervening in the different stages of the business." 


\section{Counter-intuitive routes from the borderland to the ports: the geographic incentive}

Geographic characteristics can be a facilitator and even an incentive for criminal organizations. Regarding counter-intuitive routes and ports located at the end of the world, as a former US officer claimed, "Since there is no expiration date for cocaine, they can make a trip around the world."

Chile is currently one of the main countries exporting cocaine to the European and Australian markets (JIFE 2020). Cocaine is smuggled into Chile along the northern border, which links Peru and Bolivia with the Chilean regions of Arica and Parinacota, Tarapacá and Antofagasta. It is a highly complex environment, placed between the Atacama Desert, the driest desert in the world, and the Andean high plateau. However, these geographical difficulties become opportunities for criminal organizations due to the scarce police control and the porosity of the border, which allows access without major difficulties through more than 200 illegal land crossings that are impossible to control (Troncoso 2016, 2017).

Counter-intuitive routes allow cocaine to enter Chile and then be re-exported. Bolivian cocaine enters by land via Santa Cruz de la Sierra and Oruro, to cross the border to Chilean cities. Cocaine from Peru is also transported by land, entering Chile mainly through the city of Arica. In addition, there is evidence of the use of maritime routes from the Peruvian port of El Callao. As a Chilean customs officer describes, the cocaine enters Chile through Arica and Iquique in the North. However, criminal organizations are not only using land crosses; they are also exploiting the sea as an entry point by using even semi-submergibles. Once in Chilean territory, the cocaine is transported by land along the Pan-American Highway, traveling $2000 \mathrm{~km}^{4}$ to the port of San Antonio.

Uruguay was for a long time insignificant in terms of international drug trafficking, according to a Uruguayan officer. Nevertheless, recently, it seems to be emerging as a new route for the cocaine that comes specially from Bolivia, sometimes through Paraguay and even Brazil, and Montevideo is becoming a Non-Traditional Port used to export cocaine (UNODC 2020). As a Uruguayan officer pointed out: "Significant quantities of cocaine pass through the port of Montevideo. Montevideo is a distribution center for cocaine destined for Europe, smuggled from the Paraguay and Parana rivers and other land routes." Additionally, some of the shipments can arrive by land, using the long and not very controlled border with Brazil where there are twin cities that share everyday dynamics such as Rivera-Santana do Livramento or Chui-Chuy. Further, as an Argentinean official pointed out, small planes crossing from Paraguay and Brazil were detected taking cocaine to the Uruguayan territory and landing in country areas located in the Salto and Tacuarembó departments (both close to the border with Argentina and Brazil, respectively) (El Observador 2019). According to Carlos Noria, former Commissioner General of the Directorate for the Suppression of Illicit Drug Trafficking of Uruguay, "it is not new that Uruguay is used as a transit country. What is new is the volume" (El País 2020).

\footnotetext{
${ }^{4}$ This distance is equivalent to the distance between Lisbon and Brussels.
} 
Argentina shares borders with Bolivia and Paraguay and on those borders, we can find twin cities such as Villazon-La Quiaca, Yacuiba-Salvador Mazza, Encarnación-Posadas, and Ciudad del Este - Puerto Iguazú - Foz do Iguaçu (The wellknown Triborder Area between Argentina, Brazil, and Paraguay). According to key informants, even private properties connecting Bolivia and Argentina are used to take trucks with already contaminated cargo that can enter Argentina illegally. Once in Argentina (entering through the provinces of Salta, Jujuy, Formosa, Chaco, Misiones, or Corrientes), the cargo is usually moved by land (between 1300 and $1800 \mathrm{kms}$ separate the border area from the port), using different routes and combinations of routes with Rosario or Buenos Aires as the main destinations (Sampó 2017a, 2017b). Another option to move the cocaine to the ports in the South Atlantic Ocean is to use the waterway ${ }^{5}$ linking Bolivia, Paraguay, Argentina, and Uruguay. This option is, according to Argentina's Office of the Prosecutor for Narco-Crime (PROCUNAR), more common than authorities would like to accept. Controlling the cargo during that journey is almost impossible and criminal organizations are aware of this. Ships can come from Bolivia or Paraguay with cocaine so the overseas shipment will be made from Montevideo (El País 2020) or Buenos Aires. Finally, small flights have been detected in two modalities: doing a roundtrip or going down in clandestine landing strips (more than 1500 have been detected recently) in different provinces, not always placed as close to the border as one may think (Santiago del Estero, Santa Fe, and even Buenos Aires are some examples) (Klipphan 2017). As a result of recent operations, Argentina has been added again to the map of cocaine routes as a transit country (UNODC 2020).

According to an Argentinean officer, recently a double dynamic has emerged that seems to show the growing importance of Uruguay-and probably of Argentina, too-in the international drug market: on the one hand, we have seen the entry of small planes and, on the other hand, the role of the waterway that connects two cocaine hot spots (Bolivia and Paraguay), which is the perfect corridor. The waterway starts in Bolivia, passes through Paraguay (both Mediterranean countries have a right to use it to access the sea), and travels for hundreds of kilometers in Argentinean territory until it passes through the Buenos Aires port and ends in Montevideo. In that context, an official claims:

So, basically, what I see in Argentina at the moment is that, necessarily, it has to be affected by these expanding markets (...) This has a double impact: it has an impact on international cocaine trafficking to Europe, but also on the supply of local consumer markets.

According to this Argentinean official (with the agreement of a former US and current Colombian official), this route used to have Brazil as its epicenter: "but Brazil has begun to intensify its controls, especially in the port area, and so it must necessarily move south." Colombian and US officers, as well as Peruvian and Chilean academics, agreed with this diagnosis.

\footnotetext{
${ }^{5}$ A map of the hidrovia Paraná-Paraguay can we found at: https://www.consejoportuario.com.ar/133HIDROVIA
} 
The three ports we studied are located at a great distance from the producing countries, which implies high mobility. Complex geography, porous borders, and state limitations in terms of control and corruption act as incentives and make cocaine trafficking possible through their countries.

\section{The ports of Buenos Aires, San Antonio and Montevideo: the lack of control as an incentive for criminal organizations}

The long journey that involves using counter-intuitive routes and Non-Traditional ports of cocaine departure involves higher costs for the criminal organizations but provides greater security for cocaine shipments, due to the high flow of containers and the weaknesses of the port system. We need to understand that, as a former US officer claims, criminal organizations: "run it like a business, they are criminal businesses, and that is why they are using the supply and demand market, price and also choosing where there is less surveillance." As a Chilean officer points out: "why go south? The returns are so high, and the borders closed by pandemic, drug dependents are willing to pay anything. So, the cost is ultimately borne by the customer."

Although San Antonio is the largest transfer port of Chile, it has significant vulnerabilities. A Chilean official commented: "the vulnerability is that it has grown too much, and security has not been growing in the same way", which is influenced by the fact that it is a private port, making it difficult to monitor, but also fundamentally by the lack of recognition of drug trafficking by sea, even though the maritime route is used for global trafficking (Perez 2014). As an academic highlights: "In Chile there is no recognition of the maritime issue as an important issue, everyone kind of refuses to acknowledge that this is a problem and in fact the vast majority of times that these cargoes that have been found, it is said that they were contaminated at sea."

The lack of coordination between the police (Maritime Police [DIRECTEMAR], Carabineros, Investigative Police) and Customs, which does not carry out drug seizures but decides when to open a container or not, seems to be a major problem. As one Chilean academic explained: "there is no explicit recognition of the problem of customs and ports. I think it is a huge problem and to put it in context because here there is a certain fight between customs and the police." As a result, Customs finds some incentives to perform seizures but, a Chilean officer points out, they are not interested in arresting anyone, which is supposed to be a difference from the police.

In addition, controls are deficient. One academic argues: "what is effective is that the level of checkups or concentration of police capacity in the port is very low" and continues "my impression is that there must be a significant level of corruption in the institutions." All these factors make this port attractive to criminal organizations, mainly those that use it to re-export cocaine; that is, to launder and disguise the origin of the drugs, as we will explain below.

The port of Buenos Aires is located in the capital city. Even though it is still the property of the State, its use was privatized during the 1990s. There are several private terminals inside. In the port, two different State forces co-exist. First, there is Customs, which according to a foreign trade expert has the power inside the port; 
and, second, there is Prefectura Naval, a Security Force whose role is to impose order in the port and that relies on a court order to act on suspected drug trafficking cases. State control seems to be limited and, according to the foreign trade specialist we interviewed, although "There is technology available for everything, there was no political decision to do so" especially due to competition with Montevideo, which seems to have relaxed controls in favor of greater and faster commercial movement. As a result, an Argentinean officer claimed: "In view of the competition in terms of costs that the port of Montevideo began to represent, they began to relax the controls and requirements in the Argentine ports in order to be able to compete."

In the case of Buenos Aires, even when most of the seizure containers were contaminated at origin, it is important to highlight the role of the rip-off method. Due to cost and time, most goods undergo Customs clearance where they originated before traveling by land to the port, meaning that the customs process is effectively completed before the export even arrives at the port of departure. Once in the port area, it must wait for the ship in a fiscal deposit controlled by Customs. The seals are placed before the cargo starts moving to the port and, since "God is in Buenos Aires" and ships depart more often from there, many of the producers, even those working close to other ports such as Mar del Plata or even Bahia Blanca, choose to send their cargo to Buenos Aires. The problem is that nobody controls the cargo between the moment the seals are placed and the moment when the container is put into the ship. So, as the foreign trade specialist pointed out, there are a lot of possibilities and probably temptations during the journey of the container. As Perez (2014: 28) confirms: "The introduction of this type of cargo is usually supported or assisted by port personnel, but also involves the participation of customs agents."

Another weakness of the port is related to the existence of treaties that give Paraguay and Bolivia the possibility to be in the port of Buenos Aires in transit, which means that Prefectura cannot intervene. In fact, the last cocaine cargo discovered in Antwerp and Hamburg coming from Buenos Aires (April 2021) had been there in transit from Paraguay. According to a foreign trade specialist, depending on the cargo, when it comes to bulk shipments, they may have to use a transship in Buenos Aires from the barges to the containers. The same problem arises in Montevideo since Argentina and Uruguay share the waterway and the treaties allowing Bolivia and Paraguay to access the sea. Also, recent seizures in Europe have shown that the transit is affecting both ports equally. As a Colombian Officer claimed: "There was a seizure of 23 tons between the two, which left Paraguay bound for Hamburg and Antwerp, which also says that criminal organizations are now looking for alternative routes that are not so conspicuous and that do not generate alert in the authorities of the ports of destination." A Peruvian academic concluded: "the waterway must have been one of the most important cocaine exit roads for several years" even though only recent seizures prove him correct.

\footnotetext{
${ }^{6}$ A traditional saying denoting the dominance of the city of Buenos Aires in the national imagination and reality. It reflects the view that everything happens in Buenos Aires while the interior of the country just has to deal with it or move to the big city.
} 
The dynamics of Buenos Aires and Montevideo seem to be remarkably similar. At the end of 2019, the Uruguayan Customs together with the Navy, seized 4.4 tons of cocaine (Armada Nacional de Uruguay 2019) hidden in four containers of soy flour thanks to risk analysis and the use of the port scanner (which sometimes is not operative according to a Uruguayan official). In the port of Montevideo, as happens in San Antonio and Buenos Aires, Prefectura Naval (that depends on the Uruguayan Navy) is in charge of law enforcement (Ewig 2017: 298) while Customs is responsible for seizures of illegal goods, such as psychoactive substances prohibited in the country. In the case of Uruguay, as Ewig claims (2017: 298), Customs is tasked with reducing demand and controlling the supply of drugs, as well as addressing money laundering. This mission differs from that of customs in Argentina and Chile.

According to an Argentinean officer:

You also must consider that the use of the port of Montevideo has grown a lot, due to a cost issue. Then you have a large space where the cargo, until it is loaded on the overseas vessels, you have a huge space of time to adulterate that cargo, which is also an interesting issue.

As a result, it seems important to emphasize that the bigger the volume moved in the port, the more difficult it is to control. Besides, if trade is the goal and overseas drug trafficking is not even considered as a problem, controls may be seen as a hindrance to commerce. Paradoxically, the volume of container movement reported by the ports studied may generate a more diffuse control by state institutions despite the centrality of these spaces. As a result, the authorities' denial of their role in cocaine trafficking is fueled. As a Uruguayan officer claimed: "To the extent that this does not translate into violence, the Uruguayan did not pursue it." In that sense, the three countries, unfortunately, do not seem to be concerned about what is leaving their territories and lip service is paid to drug trafficking rather than action.

From Montevideo, the containers go to West Africa (e.g., Benin, Togo) and Europe, as seizures showed (Delgado 2020). Once again, the idea of Montevideo replacing some of the shipments that used to depart from Brazil seems perfectly accurate.

One of the main problems identified by key informants is the lack of control at the ports and, in the three cases, the fact that there are overlapping jurisdictions where there is no cooperation or coordination specially between Customs and the Security forces. The port, as Perez (2014: 24) says, "is a mini-city with its own structure, rules and control mechanisms, which has several restricted areas." In that sense, the control is not only weak but also inefficient. As a Chilean academic said: "What is effective is that the level of review or concentration of police capacity in the ports is very low."

In sum, in the three ports we detected important weaknesses regarding the control of cargo and shipments, together with a clear lack of political will regarding drug trafficking to overseas ports. Further, the fact that the three ports are concentrated in commodities exports, makes the contamination easier for criminal actors, whether they are criminal organizations or brokers working independently. As a Colombian officer pointed out: "The issue of some commodities is complex because it cannot be 
detected. The scanners cannot detect it because they coat it with aluminum or other material that prevents it from being detected."

The three ports seem to share an apparent calmness behind which hides ignorance of the real situation. As a Colombian officer pointed out: "Many times it is said, nothing is happening here, it is not that it is not happening, it is that the authority does not seizure or because it is in another mission or because it has high rates of corruption and is not interested, it is as simple as that." As a Chilean officer contended: "what are the authorized passages in the oceans? if the oceans do not have customs controls, the only controls that are exercised are in the ports. But what happens on our coasts is gigantic."

In short, the porosity of land borders has its correlation in the ports, understood as the last border limit before the sea. In this sense, the weakness and inefficiency of state controls is becoming increasingly clear, opening a world of possibilities for criminal organizations based on maritime trade. This reinforces the idea that the use of counter-intuitive routes and Non-Traditional ports of cocaine departure is a rational choice for criminal organizations that aim to expand their profits.

\section{Country reputation and re-exportation of cocaine}

Another element to consider as part of the context in which ports are being used to smuggle cocaine is that the three countries currently do not have a reputation related to drug trafficking. They are not producers nor are they marked as countries used for transit by the authorities of the countries of cocaine entrance. On the contrary, especially in the case of Chile, key informants have mentioned the country reputation they strive to maintain as an incentive for criminal organizations to use their ports. As a Colombian officer has pointed out: "A ship leaving from Chile, Paraguay, Argentina, or Uruguay generates less of an alert than a ship leaving Colombia, Panama or Costa Rica. And these transitions are known by criminal organizations."

Cocaine re-export is a way to launder the cargo and disguise the origin of the drugs. For that purpose, the country's reputation is used. The "cleaner" the country's reputation in terms of cocaine trafficking, the less risky its use will be for criminal organizations, becoming an additional incentive to those mentioned above. Argentina, Chile, and Uruguay, are countries with clean reputations that do not activate the alarm system in entry countries when a ship departs.

In this sense, Chile's reputation as a country that promotes free trade and its apparent advanced security standards provide an opportunity to make re-export safer for criminal organizations by reducing the possibility of controls at destination ports. A specialist comments: "Well, that cocaine arrives in Chile in transit to captive markets in the U.S. and we have also detected that using routes that pass-through Africa they end up in Russia and obviously Europe, so they are using us, with respect to cocaine." However, one academic noted the incongruence between the seizure figures in Europe and Chile, and warned us about the possible significance of this:

Chile is the third country where seizures occur, perhaps because it is also a more insignificant actor, so it is easier to deliver in the area where it is seized, as well as here, there it is seized what is delivered, so perhaps it is easier to say 
"hey my friend" in Mexico please do not touch them and I will deliver a small boat that arrives from Chile.

It is highly probable that the number of seizures linked to departures from Chilean ports is related to the idea of "distracting" the European authorities from what enters from other, more traditional ports. In this regard, it is necessary to highlight that all the key informants emphasized that the seized shipments resulted from a leakage of information. This leads us to be more suspicious of the accuracy of Chile's position as the third country from which most cocaine seized in Europe originates.

Its location on the Pacific Ocean seems to force the departure of cocaine from Chile since the other options are Colombia, Peru, and Ecuador, all of them marked as countries to be monitored at the ports of entrance. On the contrary, on the Atlantic Ocean, the obvious choice will be Brazil, but Argentina and Uruguay are increasingly being viewed as alternatives for the departures, especially southern Brazil, as an Argentinean officer pointed out.

The use of San Antonio as a Non-Traditional Port of cocaine departure seems to be more important than the use of Buenos Aires and Montevideo. This is likely because, firstly, Chile has a better international reputation due to its role in international commerce but also because of the perception of low corruption there, as mentioned. Second, as described, it is a door to the Pacific corridor that connects South America with some of the new cocaine markets such as China, Australia, and New Zealand. Finally, Chile shares borders with two producers and Peru's production continues growing, so criminal organizations must find a way to export the drug from the region. On the contrary, the frequency in the use of Buenos Aires and Montevideo seems to be more related to the way control is managed in Brazil. Nevertheless, the incentive for criminal organizations exists and it is being used. As Mcdemott et al. $(2021,31)$ point out, many South American countries have become or are at jeopardy of becoming major cocaine export platforms, and Argentina, Chile, and Uruguay are mentioned among them.

In sum, country reputations can be used to re-export cocaine in a safer way, reducing the risk to the cargo and increasing profits for criminal organizations. According to a Brazilian officer, Non-Traditional ports and counter-intuitive routes are strategic choices used by criminal organizations to ensure higher profits.

\section{Conclusion}

The research shows that the Global South responds to the illicit drug demand imposed from the Global North. The pressure generated by the consumer markets, especially those located in the United States and Europe, leads to an increase in coca bush cultivation and cocaine production capable of flooding the region. Consequently, non-producing countries have suffered the impact of these changes, with their ports beginning to be used to supply mainly the most profitable markets. In this sense, Europe takes a central role considering that its geography allows the passage to new markets, where cocaine attracts extraordinary values. Simultaneously, 
increased controls in Colombia, Peru, and Brazil in the last three to five years have led to a shift of drug trafficking routes southward.

The main findings of this research are that the context in which the use of Buenos Aires, San Antonio, and Montevideo is prioritized is marked by the geographical, infrastructure, and socio-political factors that emanate from the countries in which the ports analyzed are located. Argentina, Chile, and Uruguay present important vulnerabilities that can be transformed into opportunities for criminal organizations. Further, we showed that criminal organizations prioritize the Ports of Buenos Aires, San Antonio, and Montevideo, and the counter-intuitive routes that lead to them, because they are spaces that generate incentives linked mainly to: 1 . The porosity of borders; 2. Lack of control at the ports; and 3. The possibility of using the country's reputation to re-export cocaine. In addition, counter-intuitive routes and Non-Traditional Ports of cocaine departure represent the possibility of increasing the profit margin of their business, compared to in the traditional routes where the criminal organizations contemplate a $20 \%$ loss.

The research shows that key actors, like Security Forces, have a profound lack of knowledge about what goes on inside the port facilities. The study of the ports of Buenos Aires, San Antonio, and Montevideo reveals that there is no recognition by state authorities of drug trafficking as a problem, beyond the discursive. These ports remain off the radar of the authorities at ports of cocaine entry. However, the data collected during the research indicates that these ports are relevant for the re-export of cocaine, as they launder and disguise the origin of the drugs by taking advantage of countries' reputations.

In these ports, it is clear that criminal organizations favor low risk over logistical costs, geographic distance and even the time it takes them to move the cargo. Likewise, the rational calculation that leads criminal organizations to opt for these ports of cocaine departure (low-risk, high return) is evident, as these routes improve their profits significantly.

The maximization of benefits is given not only by the low risk involved in the use of Non-traditional Ports of cocaine departure but also because its use generates a diversion of the attention of the authorities of the traditional ports, from which greater volumes of cocaine can then be moved.

From the work carried out, it is possible to discern the emergence of at least four new lines of research: 1. Cocaine trafficking from landlocked countries, such as Bolivia and Paraguay; 2. The role of the waterway Paraná-Paraguay; 3. The link between Non-Traditional ports of cocaine departure and new markets such as China, New Zealand, and Australia; and 4. Other Non-Traditional Ports of cocaine departure, which are not containerized. Also, since the lack of control seems to attract more crime and too much control displaces crime (Eski 2016, Sergi and Storti 2020, Sergi 2020c), it is necessary to work on what strategies can be used to prevent drug trafficking effectively.

The trends we described in this article existed before the Covid-19 crises, but they have deepened since the end of 2020. Unfortunately, cocaine trafficking is expected to rise even more due to the growing demand from traditional (The United States and Europe) and new markets (Oceania and Asia). At the same time, criminal organizations may become more sophisticated through access to greater economic 
resources and a better logistical capacity. Finally, due to the economic crisis caused by the pandemic, flexibility in port regulatory frameworks to enhance the countries' foreign trade may contribute to an increase in the movement of cocaine via the sea.

\section{Declarations}

Ethical statements The manuscript is submitted only to Trends in Organized Crime. It is also an original piece, unpublished in each one of its parts. The authors declare that the data presented in the article are their own. We also have cited appropriately all the relevant literature we have found.

Interviews were made off the record and due to the sensitivity of the topic, key informants asked to remain anonymous. We have consent to reproduce their words only if name and title remains confidential. We think it is not proper to publish the interviews since in many of them the informants talk about their positions and sensitive information that may compromise their jobs.

\section{References}

Anguita Olmedo C (2020) Dynamics of organized crime in the European Union in the context of global insecurity. In: Conde E (Editor in chief), Yaneva Z, Scopelliti M (co-editors) The Routledge Handbook of European Security Law and Policy, Routledge, London, pp 175-197

Antonelli M (2020a) An exploration of organized crime in Italian ports from an institutional perspective. Presence and activities. Trends Organ Crim. https://doi.org/10.1007/s12117-020-09400-Z

Antonelli M (2020b) I sistemi portuali e gli spazi della criminalità organizzata. In: Dundovich E, Partecipazione, conflitti e sicurezza. Pisa University Press, Pisa, pp 17-28

Arias E (2006) The dynamics of criminal governance: networks and social order in Rio de Janeiro. J Lat Am Stud 38:293-325. https://doi.org/10.1017/S0022216X06000721

Arias E (2017) Criminal enterprises and governance in Latin America and the Caribbean. Cambridge University Press. https://doi.org/10.1017/9781316650073

Armada Nacional de Uruguay (2019) Incautación en el Puerto de Montevideo. Available at: https://www. armada.mil.uy/index.php/noticias/341-incautacion-en-el-puerto-de-montevideo

Augé M (1993) Los no lugares. Espacios del anonimato, una antropología de la sobre modernidad. Barcelona, Editorial Gedisa

Bartolomé MC (2016) Drogas y violencia: Colombia, Venezuela, México y Argentina. ESGlobal, Abril 14. Available at: https://www.esglobal.org/drogas-y-violencia-colombia-venezuela-mexico-y-argen tina/

Bartolomé MC (2019) El papel de Bolivia dentro de los esquemas del tráfico de cocaína. Real Instituto Elcano, ARI 102/2019. Available at http://www.realinstitutoelcano.org/wps/portal/rielcano_es/conte nido?WCM_GLOBAL_CONTEXT=/elcano/elcano_es/zonas_es/ari102-2019-bartolome-venturapapel-de-bolivia-dentro-de-esquemas-del-trafico-de-cocaina

Bartolomé MC, Ventura VM (2020) Narcotráfico en América del Sur más allá del bloque andino: los casos de Argentina y Brasil. Revista De Relaciones Internacionales, Estrategia Y Seguridad, 14 (1): 205-222. https://doi.org/10.18359/ries.3760

Bueger C, Edmunds T (2020) Blue crime: Conceptualising transnational organised crime at sea Política Maritime 119. https://doi.org/10.1016/j.marpol.2020.104067

CEPAL (2019) Informe de la actividad portuaria de América Latina y el Caribe 2018. Available at:https:// www.cepal.org/es/notas/informe-la-actividad-portuaria-america-latina-caribe-2018

CEPAL (2020) Los efectos del COVID-19 en el comercio internacional y la logística. Informe especial COVID-19 $\mathrm{N}^{\circ}$ 6. Naciones Unidas. Available at:https://www.cepal.org/es/publicaciones/45877efectos-Covid-19-comercio-internacional-la-logistica

CIMCOM (2018) Narcotráfico marítimo: fenómeno transnacional que afecta la seguridad continental. Colombia, Armada Nacional República de

CIMCON (2020) Catálogo de modalidades de narcotráfico marítimo. Edición $\mathrm{N}^{\circ} 1$. Available at: http:// www.cicad.oas.org/main/aboutcicad/activities_spa.asp?IE=BS0215 
Delgado J (2020) Uruguay detiene mayor cargamento de cocaína de su historia Diálogo, Revista Militar Digital. Available at: https://dialogo-americas.com/es/articles/uruguay-detiene-mayor-carga mento-de-cocaina-de-su-historia/

El Observador (2019) Al menos cuatro bandas ingresaron droga en avionetas en los últimos diez años. Available at: https://www.elobservador.com.uy/nota/al-menos-cuatro-bandas-ingresaron-drogaen-avionetas-en-los-ultimos-diez-anos-201991715553 Recovered 20/02/21

El País (2020) La cocaína universal, 12/13/2020. Available at: https://elpais.com/internacional/202012-12/la-cocaina-universal.html. Recovered 18/01/21

Ewig G (2017) El crimen organizado de las drogas ilegales en el Uruguay del siglo XXI. Una aproximación normativa y cuantitativa, Revistas de la Facultad de Derecho 43:342-382

Fiscalía de Chile (2020) Observatorio del narcotráfico. Informe 2020. Ministerio Público, Santiago. Available at: http://www.fiscaliadechile.cl/Fiscalia/quienes/observatorionarcotrafico2020. jsp. Recovered 01/12/21

Guterres A (2020) 2020. UN secretary-General's message. United Nations. Available at: https://www. un.org/en/observances/maritime-day/messages. Recovered 01/08/21

Hobbs D, Antonopoulos G (2014) How to research organized crime. In: Paoli L (ed) The Oxford handbook of organized crime. Oxford University Press, Oxford, pp 96-117

Idler A (2019) Borderland battles: violence, crime, and governance at the edges of Colombia's war. Oxford University Press, Oxford

Jenss A (2020) Global flows and everyday violence in urban space: the port-city of Buenaventura, Colombia. Polit Geogr 77. https://doi.org/10.1016/j.polgeo.2019.102113

JIFE (2020) Informe de la Junta Internacional de Fiscalización de Estupefacientes correspondiente a 2019. Naciones Unidas, Viena. Available at: https://www.incb.org/documents/Publications/ AnnualReports/AR2019/Annual_Report/Spanish_ebook_AR2019.pdf. Recovered 01/18/21 Available at: https://www.lanacion.com.ar/el-mundo/coronavirus-reino-unido-incautaron-14kilos-cocaina-nid2354617

Klipphan A (19 de agosto 2017). La mafia de los narcoaviones por dentro. Infobae. Availability at: https://www.infobae.com/sociedad/2017/08/19/la-mafia-de-los-narcoaviones-por-dentro/

Labrousse A (2012) Geopolítica de las drogas. Santiago, LOM Ediciones

Lantsman L (2017) Seaport vulnerability to criminal networks: a mixed method approach to measuring criminological vulnerability in the top 30 U.S. container ports. CUNY academic works. Availability at: https://academicworks.cuny.edu/gc_etds/2009/. Recovered 01/06/2021

Lefebvre H (2013) La producción del espacio. Capitan Swing Libros, Madrid

Lessing B (2020) Conceptualizing criminal governance. Perspectives on Politics, First View, pp1-20. https://doi.org/10.1017/S1537592720001243

Madsen C (2018) Pacific gateway: state surveillance and interdiction of criminal activity on Vancouver's waterfront. Salus Journal, 6 (1) 26-43. Availability at: https://search.informit.org/doi/10. 3316/informit.483369298415687. Recovered 01/12/2021

Massey D (2012) Un sentido global del lugar. Icaria Espacio críticos, Barcelona

McDermott J et al (2021) The cocaine pipeline to Europe. Global Initiative Against Transnational Organized Crime \& Insight Crime. Availability at: https://globalinitiative.net/analysis/cocai ne-to-europe/

Moiseienko A, Reid A, Chase I (2020) Improving governance and tackling crime in free-trade zones. Royal United Services Institutee for Defence and security studies, London. Availability at: https://rusi.org/publication/occasional-papers/improving-governance-and-tackling-crime-freetrade-zones. Recovered 01/12/2021

Morselli C, Royer M-N (2008) Criminal mobility and criminal achievement. J Res Crime Delinq 45(1):4-21. https://doi.org/10.1177/0022427807309630

Pérez A (2014) Mares de Cocaína. Las rutas náuticas del narcotráfico. Grijalbo, México D.F

Roks R, Bisschop L, Staring R (2020) Getting a foot in the door. Spaces of cocaine trafficking in the Port of Rotterdam Trends Organ Crim. 101007/s12117-020-09394-8

Sampó C (2017a) Narcotráfico y trata de personas, una muestra de cómo el crimen organizado avanza en Argentina. Revista Relaciones Internacionales, Estrategia y Seguridad 12 (2), pp. 267-286. 10.18359/ries.2774

Sampó C (2017b) "El tráfico de droga en la Argentina: Estado de la cuestión, cuestión de Estado" Revista Sociales en Debate, 11, Facultad de Ciencias Sociales, Universidad de Buenos Aires, 82-89 
Sampó C (2019a) De la reclusión en las prisiones al control del tráfico de cocaína: la evolución de las organizaciones criminales brasileñas., DT 11/2019 Real Instituto Elcano. Available at http:// www.realinstitutoelcano.org/wps/wcm/connect/d7fd07d1-ca0d-45a4-b227-6010c63a6cbb/DT112019-Sampo-reclusion-prisiones-control-trafico-cocaina-evolucion-organizaciones-criminalesbrasilenas.pdf?MOD=AJPERES\&CACHEID=d7fd07d1-ca0d-45a4-b227-6010c63a6cbb. recovered $22 / 01 / 21$

Sampó C (2019b) El tráfico de cocaína entre América Latina y África Occidental URVIO, Revista Latinoamericana De Estudios De Seguridad, (24):187-203. https://doi.org/10.17141/urvio.24. 2019.3700

Sampó C, Ferreira M (2020) De la fragmentación de las estructuras criminales a una proto-mafia: un análisis del Primeiro Comando da Capital (PCC) en Sudamérica. Revista de Estudios en Seguridad Internacional 6(2):101-115. 10.18847/1.12.6

Sampó C, Quirós L (2018) "Las estructuras criminales en Argentina y las iniciativas de cooperación estatal a fin de combatir su avance" Revista de la Sociedad Argentina de Análisis Político 12(2):337-358

Santos M (1996) De la totalidad al lugar. Oikos Tau, Barcelona

Sergi A (2020a): Policing the port, watching the city. Manifestations of organised crime in the port of Genoa Policing and Society. https://doi.org/10.1080/10439463.2020.1758103

Sergi A (2020b) The port-crime Interface: a report on organised crime and corruption in seaports. Kindle Direct Publishing \& Amazon Media

Sergi A (2020c) Playing Pac-Man in Portville: policing the dilution and fragmentation of drugs importations through major seaports. Eur J Criminol. https://doi.org/10.1177/1477370820913465

Sergi A, Storti L (2020) Survive or perish: organised crime in the port of Montreal and the port of New York/New Jersey. Int J Law, Crime Justice 63:100424. https://doi.org/10.1016/j.ijlcj.2020. 100424

Sergi, A. et al (2020) SECUR.PORT workshop: a conceptual report and summary of activities. Ghent University, University of Essex, RUSI

Souto Zabaleta M, Delfino P, Sarti SS (2019) Consideraciones críticas sobre el abordaje del problema del narcotráfico en Argentina. Revista IUS 13(44):51-88. 10.35487/rius.v13i44.2019.466

Swedberg R (2020) Exploratory Research. In: C. Elman C, J. Gerring J, Mahoney J (eds) The Production of Knowledge: Enhancing Progress in Social Science (Strategies for Social Inquiry, págs. 17-41). Cambridge: Cambridge University Press, oo, 17 -41

Transparency International (2021) Corruption perceptions index. Availability at: https://www.trans parency.org/en/cpi/2020/index/ury

Troncoso V (2016) Una aproximación al crimen organizado en la Triple Frontera de Bolivia, Chile y Perú. Debates Latinoamericanos 14 (29), pp 130-149. Availability at: https://revistas.rlcu.org.ar/ index.php/Debates/article/view/314

Troncoso V (2017). Narcotráfico y el desafío a la seguridad en la triple frontera andina. Rev.relac.int. estrateg.segur 12(1): 103-130. 10.18359/ries.2466

UNCTAD (2020) Review of maritime transport. United Nations Publications, New York. Available at: https://unctad.org/webflyer/review-maritime-transport-2020

UNODC (2019) World drug report 2019. United Nations publication, Vienna. Available at: https:// wdr.unodc.org/wdr2019/

UNODC (2020) World drug report 2020, booklet 3: drug supply. United Nations publication, sales no. E.20.XI.6, Vienna. Available at: https://wdr.unodc.org/wdr2020/en/drug-supply.html

UNODC (n.d.-a) CCP Glossary of Terms. Available at:https://www.unodc.org/ropan/en/BorderControl/container-control/ccp-glossary-of-terms.html

UNODC (n.d.-b) UNODC-OMA Programa Global de Control de Contenedores. Available at:https:// www.unodc.org/ropan/es/BorderControl/container-control/ccp.html

Vander Beken T, Drefruytier M (2004) Measure for measure methodological tools for assessing the risk of organised crime. In: van Duyne P et al (eds) Threats and phantoms of organised crime, corruption and terrorism; rhetoric and critical perspectives. Wolf Legal Publishers, pp 51-84

Von Lampe K (2004) Measuring Organised Crime A Critique of Current Approaches. In: van Duyne $\mathrm{P}$ et al (eds) Threats and Phantoms of Organised Crime, Corruption and Terrorism; Rhetoric and critical perspectives. Wolf Legal Publishers, pp 85 -116

Von Lampe K (2015) Organized crime: analyzing illegal activities, criminal structures, and extralegal governance. SAGE Publications, London 
World Economic Forum (2019) The Global Competitiveness Report 2019. Available at: https://www. weforum.org/reports/how-to-end-a-decade-of-lost-productivity-growth

Zaitch D (2001) Traquetos : Colombians involved in the cocaine business in the Netherlands, PhD Thesis, Universiteit van Amsterdam, Amsterdam: Bureau Grafische Produkties UvA

Zaitch D (2002) From Cali to Rotterdam: perceptions of Colombian cocaine traffickers on the Dutch port. Crime, Law \& Social Change 38:239-266. https://doi.org/10.1023/A:1020691532717

Zaitch D Antonopoulo G (2019) Organised crime in Latin America: an introduction to the special issue trends in organized crime 22:141-147. https://doi.org/10.1007/s12117-019-09364-9

Publisher's note Springer Nature remains neutral with regard to jurisdictional claims in published maps and institutional affiliations. 